\title{
Preparing Technical Communication Students for Workplace Practitioner Research
}

\author{
Marjorie Rush Hovde \\ Indiana University-Purdue \\ University Indianapolis \\ mhovde@iupui.edu
}

\begin{abstract}
Practitioner research in technical communication differs from general or academic research. Technical communication students need to develop abilities to conduct research into subject matter, audience, and communication approaches within workplace contexts to meet situated needs. This article explores differences between the two realms of research and discusses implications for teaching practitioner research abilities. It closes with examples of and ideas for teaching practitioner research abilities to technical communication students. Such courses can provide students with crucial abilities and knowledge to guide decisions during the creation of technical communication products.
\end{abstract}

Index Terms - Practitioner research, teaching applied research abilities in technical communication.

\section{INTRODUCTION}

Practicing technical communicators need to conduct research effectively in order to learn about audience, subject matter, and communication approaches [1]-[3].

Technical communicators cannot communicate only about what they already know; they have to learn about subject matter, so research plays an important role in the invention process [4]. Technical communicators also conduct research about audience and communication approaches in order to make evidence-based decisions in what Spilka terms "practitioner research" [3].

If graduates are not prepared to conduct practitioner research, they tend to use "unsystematic approaches to solving workplace problems" [1, p. 225] which can lead to ineffective technical communication. Overall, "Research methods course work plays a crucial role in curricula for preparing professionals for their future careers in both academe and industry" [1, p. 225]. However, preparing students to conduct research that influences workplace practice differs from preparing them for academic research.

This article explores the nature of applied, practitioner research as it differs from academic research, a variety of challenges in teaching applied research to technical communication students, and several approaches for teaching practitioner research abilities.

\section{THE NATURE OF TECHNICAL AND PROFESSIONAL COMMUNICATION PRACTITIONER RESEARCH}

Several organizations provide examples of using applied technical or professional communication research to guide their decisions in creating technical/professional communication products. For instance,

- A user-experience team conducts test to determine if plain-language documentation works for intended readers at Healthwise. The team also interviews patients to assist in developing personas to guide the design of health communication materials. Healthwise conducts formative and summative usability testing as a way of learning about users and to ensure that users'communication needs are met [5].

- Civic Design conducted usability tests of Minnesota's absentee voting ballot in a public library. They completed two rounds of testing which led to an improved ballot for the state [5].

- Common Terms conducted observational research of users to see how they reacted to changes in how terms of service are presented online [5].

This applied empirical research differs from academic research in several ways because academic or general research addresses general questions, providing insights that apply to many situations while applied research addresses situated questions, providing answers that apply to specific contexts.

The two types of research overlap in places, but goals, resources available, and dissemination opportunities [3] vary according to contextual factors, including "varying user needs, writer-user relationships, time and cost constraints, and other elements" [6, p. 382]. Resources for applied technical communication research also may vary according to the culture of the company, the size of the technical communication team, and attitudes toward the value and role of technical communication.

Table 1 provides an overview of how these two realms of research may differ. 
TABLE 1. KEY DIFFERENCES BETWEEN ACADEMIC AND PRACTITIONER RESEARCH.

\begin{tabular}{|c|c|c|}
\hline & Academic & Workplace \\
\hline $\begin{array}{l}\text { Questions and } \\
\text { topics for } \\
\text { research }\end{array}$ & $\begin{array}{l}\text { Questions are broadly applicable. Ex: } \\
\text { How do users navigate online help in } \\
\text { general? } \\
\text { - Researchers may study technical } \\
\text { communication approaches } \\
\text { - Researchers may study technical } \\
\text { communicators' practices in workplaces }\end{array}$ & $\begin{array}{l}\text { Questions may be applicable only to a } \\
\text { limited situation Example: How do our } \\
\text { users navigate through our company's } \\
\text { online help? } \\
\text { Researchers may study communication } \\
\text { approaches [7], subject matter [4], [8], } \\
\text { and/or their audiences [6], [9] as they } \\
\text { apply to an organization's situation. }\end{array}$ \\
\hline Resources & $\begin{array}{l}\text { - Researchers may receive grants and/or } \\
\text { release time from teaching in order to } \\
\text { conduct research. }\end{array}$ & $\begin{array}{l}\text { Practitioners may argue for time and } \\
\text { resources dedicated to conducting situated } \\
\text { research. } \\
\text { Practitioners may have access to users, } \\
\text { subject matter experts, and/or relevant } \\
\text { organizational publications such as } \\
\text { technical specifications, blueprints, or } \\
\text { wireframes. They may also be able to } \\
\text { work with design teams to conduct } \\
\text { research. } \\
\text { Practitioners may be able to conduct }\end{array}$ \\
\hline Constraints & $\begin{array}{l}\text { - } \quad \text { Researchers may have limited access to } \\
\text { practitioners and other workplace } \\
\text { resources. Hence, they tend to study } \\
\text { students and extrapolate findings to } \\
\text { workplaces [10] } \\
\text { Academics have many demands on their } \\
\text { time and may not be able to conduct }\end{array}$ & $\begin{array}{l}\text { - Managers may not understand the need for } \\
\text { technical communicators to be granted } \\
\text { research time and resources [9] in the } \\
\text { midst of tight deadlines. }\end{array}$ \\
\hline Ethics & $\begin{array}{l}\text { Academic institutions require Institutional } \\
\text { Review Board (IRB) approval for human } \\
\text { subjects research that will be published }\end{array}$ & $\begin{array}{l}\text { - } \begin{array}{l}\text { Research project may not require IRB } \\
\text { approval }\end{array}\end{array}$ \\
\hline Rewards & $\begin{array}{l}\text { - Research grants and publications typically } \\
\text { lead to promotion and tenure } \\
\text { Extensive publishing enhances an } \\
\text { academic's status among colleagues }\end{array}$ & $\begin{array}{l}\text { - Workplace research typically leads to } \\
\text { improved technical communication } \\
\text { products }\end{array}$ \\
\hline $\begin{array}{l}\text { Approaches } \\
\text { and foci }\end{array}$ & $\begin{array}{l}\text { Methods [6]) are fixed in research } \\
\text { traditions with little room for variation. } \\
\text { Academics may focus on rigor and/or an } \\
\text { elegant design of methods [11] } \\
\text { - Secondary research is usually included, } \\
\text { sometimes by itself and sometimes in } \\
\text { conjunction with primary research [12] }\end{array}$ & $\begin{array}{l}\text { - Practitioner research may include } \\
\text { improvisational "practices" [6] that differ } \\
\text { from established methods. } \\
\text { - Practitioners may not be able to be as } \\
\text { rigorous or elegant given the constraints } \\
\text { and resources of a workplace situation } \\
\text { - Methods need to be adaptable and lead to } \\
\text { - } \quad \text { Practical insights. } \\
\text { - } \quad \text { Practitioners may consult published } \\
\text { Practitioners and their supervisors may } \\
\text { value quantitative approaches over } \\
\text { qualitative ones. }\end{array}$ \\
\hline Uses of results & $\begin{array}{l}\text { - } \\
\text { pesults are shared widely in professional } \\
\text { - } \\
\text { Results advance general knowledge/theory } \\
\text { in technical communication }\end{array}$ & $\begin{array}{l}\text { - } \\
\text { - } \quad \text { Results are shared only within the } \\
\text { Results guide decisions about specific } \\
\text { technical communication products for the } \\
\text { organization }\end{array}$ \\
\hline
\end{tabular}


Both kinds of research are valuable within their contexts, but academic programs frequently encourage the first category especially for graduate students, assuming they will become academic researchers [11]. However, programs in technical communication also prepare students to become practitioners who conduct situated research in workplace contexts [1]. If students are aware of the differences explored in Table 1, they will be prepared for challenges they face upon entering technical communication practice. Technical communication programs often require client projects that involve many types of research to assess client needs, and this article provides insights and approaches that can assist students as well as practicing technical communicators.

Practitioners need to know how to adapt typical research practices within a workplace context because situated research often requires the use of "practices" which are distinct from "methods;" these practices are "contextdependent actions guided but not wholly determined by conventional heuristics, procedures, and tools" [6, p. 382]. For instance, researchers at Healthwise who are unable to reach intended users confer instead with people in the organization who have extensive experience with target users, [5] an adaptive practice similar to what Hovde [9] observed.

Technical communication students and practitioners seeking content knowledge also need to know that "information literacy" involves knowing when more information is needed and knowing how to "locate, evaluate, and use effectively the needed information" [8, p. 63].

Technical communicators need to assess workplace resources and constraints quickly in order to be effective. For instance, if they work in an Agile development environment, specifications may not be available, so they may devise alternative approaches for learning about subject matter.

Because practitioners may work in contexts where colleagues do not see the value of research [4], they may need to argue for time and access to resources that will enable them to conduct research into audience, subject matter, and/or communication approaches so that they can use the results to make data-driven decisions when creating technical communication. Understanding the nature and dynamics of applied workplace research can assist practitioners in making those arguments. The next section explores potential approaches to teaching practitioner research abilities amidst challenges.

\section{TEACHING PRACTITIONER RESEARCH IN TECHNICAL COMMUNICATION}

Technical communication students need to develop "flexible intelligence" [6, p. 406] in order to adapt traditional research methods to workplace practices. Fortunately, a few thinkers have provided insights into how to teach practitioner research approaches in technical communication.
Although Ford and Newmark [13] focus on having students write research reports for academic audiences, others focus on workplace contexts. For instance,

- Rupert and Loudermilk argue for teaching observational ethnographic methods so students can conduct site research prior to creating manuals [14].

- Cargile Cook integrates a variety of research approaches into service learning, combining secondary research with primary approaches [12].

- Scott teaches situated user-centered design research abilities in service-learning contexts [6].

Teaching academic research approaches and conventions has a long history, well-established practices, and a good number of resources, but teaching practitioner research is less well established, bringing up several challenges, including finding an appropriate textbook and finding sample reports or examples of applied research.

Several textbooks offer approaches to academic research in technical communication, but few focus adequately on practitioner research. For instance, Hughes and Hayhoe blend workplace and academic research in ways that may lead to student confusion. The text also seems to be designed to teach practitioners how to read research rather than conduct applied research in workplace contexts [15]. Porter and Coggin wrote a rare textbook designed to teach specifically about practitioner research in technical communication; unfortunately, it is many years out of print [16].

Examples of research reports can be useful in teaching students the conventions and dynamics of such work. Reports of academic or general empirical research in technical communication abound in the field's journals, but finding reports from practitioner research in technical communication is difficult because, as Spilka notes, practitioners typically do not publish articles in journals; additionally, companies concerned about proprietary issues may prevent research reports from being shared [3]. Some examples of workplace applied research reports do exist, but they are not easy to find. Examples of such resources include [7], [17]-[20].

These examples and others can be useful to students to help them understand the dynamics of practitioner research and to understand how they might create reports that differ from typical academic reports of research.

\section{A SAMPLE COURSE IN APPLIED TECHNICAL/PROFESSIONAL COMMUNICATION PRACTIONER RESEARCH}

To benefit technical communication students, I have designed and taught a course in conducting applied workplace research in technical communication. (See Appendix A for a basic syllabus). 
In this online course, upper-level undergraduate and graduate students conduct research for a client who needs to learn about audience, content, and/or communication approaches in order to create technical or professional communication.

The course begins with students reflecting on their current knowledge, creating effective research questions, and then conducting secondary research to begin to address and refine those questions. Next, they design four or five tentative empirical/primary approaches after reading resources that I have developed because I could not find an appropriate textbook.

After receiving feedback on those tentative designs, they revise one or two approaches and submit a research plan to the client for approval. Upon approval, students carry out the research and create a report to the client that provides insights based on their secondary and primary research, recommending how those findings might guide future technical/professional communication decisions. In this course, students learn about the complexities of conducting applied research and of reporting results to a specific client, results the client can use in shaping future technical or professional communication products.

In this course, we explore the possibilities and limitations of various research approaches so that students develop the flexibility to adapt approaches as needed in workplace contexts. Students learn applied practitioner research that will benefit them as they move into workplace technical and professional communication where, ideally, they make communication decisions based on insights gained through applied research.

\section{REFERENCES}

[1] K. S. Campbell, "Research methods course work for students specializing in business and technical communication," J. Bus. Tech. Commun., vol. 14, no. 2, pp. 223-241, 2000.

[2] J. D. Ford and J. Newmark, "Emphasizing research (further) in undergraduate technical communication curricula: Involving undergraduate students with an academic journal's publication and management," J. Tech. Writing Commun., vol. 41, no. 3, pp. 311-324, 2011.

[3] R. A. Spilka, "Practitioner research instruction: A neglected curricular area in technical communication undergraduate programs," J. Bus. Tech. Commun., vol. 23, no. 2, pp. 216-237, 2009.

[4] M. R. Hovde, "Research tactics for constructing perceptions of subject matter in organizational contexts: An ethnographic study of technical communicators," Tech. Commun. Quart., vol. 10, no. 1, pp. 59-95, 2001.

[5] R. Willerton, Plain Language and Ethical Action: A Dialogic Approach to Technical Content in the Twenty-First Century. New York: Routledge, 2015.
[6] J. B. Scott, "The practice of usability: Teaching user engagement through service-learning," Tech. Commun. Quart., vol. 17, no. 4, pp. 381-412, 2008.

[7] E. C. Wisniewski et al., "Development and evaluation of safety symbols for landscaping products," in Proc. Human Factors and Ergonomics Society Annu. Meeting, 200 7, pp. 1109-1113.

[8] D. G. Ross, 'Defining 'research:' Undergraduate perceptions of research in a technical communication classroom," J. Tech. Writing Commun., vol. 44, no. 1, pp. 61-99, 2014.

[9] M. R. Hovde, "Tactics for building images of audience in organizational contexts: An ethnographic study of technical communicators," J. Bus. Tech. Commun., vol. 14, no. 4, pp. $395-$ 444, 2000.

[10] M. R. Hovde, "Factors that enable and challenge international engineering communication: A case study of a United States/British design team," IEEE Trans. Prof. Commun., vol. 57, no. 4, pp. 242-265, 2014.

[11] A. Blakeslee, "The technical communication research landscape," J. Bus. Tech. Commun., vol. 23, no. 2, pp. 129-173, 2009.

[12] K. Cargile Cook, "Service learning and undergraduate research in technical communication programs," Programmatic Perspectives, vol. 6, no. 1, pp. 27-51, 2014.

[13] J. D. Ford et al., "The two- semester thesis model: Emphasizing research in undergraduate technical communication curricula," J. Tech. Writing Commun., vol. 39, no. 4, pp. 433-453, 2009.

[14] A. W. Rupert and S. Loudermilk, "Using ethnographic research practices for technical writing assignments: Developing a manual for employees," Bus. Commun. Quart., vol. 65, no. 2, pp. 67-81, 2002.

[15] M. A Hughes and G. F. Hayhoe, A Research Primer for Technical Communication: Methods, Exemplars, and Analysis. New York: Laurence Erlbaum Associates/Taylor and Francis, 2008.

[16] L. R. Porter and W.O. Coggin, Research Strategies in Technical Communication. New York: Wiley Technical Communication Library/John Wiley and Sons, 1996.

[17] T. D. Giles and B. Still, "A syntactic approach to readability," J. Tech. Writing Commun., vol. 35, no. 1, pp. 47-70, 2005.

[18] R. Walton, "How trust and credibility affect technologybased development projects," Tech. Commun. Quart., vol. 22, no. 1, pp. 85-102, 2013.

[19] Kliemann Group. (2013, Nov. 20). "Know before you owe: Post-proposal consumer testing of the Spanish and refinance integrated TILA-RESPA disclosures." [Online]. Available: https://s3.amazonaws.com/files.consumerfinance.gov/f/201311 cfpb_report_tila-respa_testing-spanish-refinancing.pdf 
[20] P. Lannero. (2013, April 30). "Fighting the biggest lie on the Internet: The CommonTerms Beta Proposal." Metamatrix AB, Stockholm, Sweden. [Online]. Available: http://www.commonterms.net/commonterms_beta_proposal.pdf

\section{ABOUT THE AUTHOR}

Marjorie Rush Hovde, an Associate Professor of Technical Communication at Indiana University-Purdue University Indianapolis, teaches a variety of graduate and undergraduate courses in technical communication. Her research features observational studies of technical communication practices and practitioners in workplaces. 


\section{APPENDIX A: BASIC SYLLABUS FOR RESEARCH APPROACHES IN TECHNICAL \& PROFESSIONAL COMMUNICATION}

\section{Research Approaches for Technical \& Professional Communication}

In creating technical and professional communication, the processes of learning are crucial and complex. Professional and technical communicators need to know how to learn quickly and well. In this course, in order to produce high quality publications we will focus on how to learn about content, audience, and communication approaches.

Learning Objectives

At the end of this course, you will be able to

- Generate effective research questions, suitable for workplace technical/professional communication research into audience, content, and communication approaches.

- Conduct and report on results of secondary research relevant to technical/professional communication.

- Design, conduct, and report on the results of primary research relevant to technical/professional communication.

- Explain the rationale for technical/professional research approaches, based on sound concepts and noting the capabilities and limitations of various approaches.

\section{Textbook}

Research Approaches for Technical and Professional Communicators. Hovde. Available online through the Canvas Learning Management System.

Course Modules

In learning how to learn about content, audience and document design, we will explore how to conduct both primary/secondary (direct/indirect) research through completing the following modules. I will provide details for each Module in Canvas as the semester progresses.

Module 1 10\%. Orientation. Becoming familiar with the online course environment (1 week)

Module 2 10\%. Questions for the semester's research. Generating questions, generating answers (2 weeks)

Module $310 \%$. Preliminary annotated bibliography of secondary sources. Indirect secondary approaches to research (3 weeks)

Module 4 30\%. Tentative primary research designs. (A collection of four assignments.) Direct primary approaches to applied research (5 weeks)

Module 5 10\%. Research plan. Designing and conducting research (2 weeks)

Module $630 \%$. Final oral and written report for the client. Analyzing, evaluating, and writing about the findings of research (3 weeks) 